\title{
Stability evaluation of Sermo dam, Yogyakarta, using two components acceleration time histories causes by Java subduction earthquake scenarios
}

\author{
Windu Partono ${ }^{1, *}$ and Undayani Cita Sari ${ }^{1}$ \\ ${ }^{1}$ Civil Engineering Department, Diponegoro University, 50275 Semarang, Indonesia
}

\begin{abstract}
Dam assessment under a specific earthquake event is one of the most important approaches to dam evaluation. The assessments are usually performed by running two different models of seismic loads: spectral acceleration and acceleration time histories. The first model is implemented using seismic load information developed from a national code. The second approach is implemented using earthquake scenarios by conducting acceleration time histories. The National Center for Earthquake Studies 2017 suggested that a shallow crustal fault and subduction are the two most dangerous seismic sources of Yogyakarta Province. This paper presents an evaluation of Sermo dam in terms of dam displacement and peak ground acceleration (PGA) under the Java subduction source earthquake scenarios. The evaluation was performed by conducting twocomponent (north-south and east-west directions) acceleration time histories from Java subduction seismic sources. Due to incomplete data, all acceleration time histories used in this study were collected and modified from worldwide earthquake data bases. Based on the average displacement and PGA values it can be predicted that Sermo dam is strong enough to resist an earthquake with a maximum magnitude of $8.4 \mathrm{Mw}$ and minimum epicentre distance of approximately $160 \mathrm{Km}$ caused by the Java subduction source.
\end{abstract}

\section{Introduction}

Sermo dam is a typical rockfill-embankment vertical zone dam with an impermeable clay zone located in the centre of the dam body. This impermeable clay zone is located at the core zone of the whole body of the dam structure. Basically, the whole body of Sermo dam structure can be separated into four different zones: the core zone in the centre, a shell zone covered with rockfill rip-rap at the outer part, a transition zone, and a filter zone between two core and shell zones. Based on information from the Department of Public Works (1994), this dam is 52.6 meters high and 160 meters long. Sermo dam was constructed between March 1994 and February 1996. The dam structure is located at $110.167^{\circ}$ longitude and $-7.833^{\circ}$ latitude or approximately $35 \mathrm{Km}$ from Yogyakarta city.

* Corresponding author: windu_bapake_dila@yahoo.com 
Sermo dam is located close to the south Java megathrust subduction source. Based on the location of Sermo dam, the closest distance to Java subduction trace is approximately $265 \mathrm{Km}$. Figure 1 shows the location of Sermo dam and its position in relation to Java subduction sources. Figure 2 shows a cross-section of Sermo dam at station 12 (Department of Public Works, 1994).

Due to its position, this dam structure is located close to dangerous seismic sources. Evaluation of the dam safety in terms of dam stability and peak ground acceleration (PGA) under seismic force is one of the most important processes for dam mitigation. This paper describes the stability evaluation of Sermo dam under south Java subduction earthquake scenarios. The analysis was performed by conducting two-component acceleration time histories [north-south (NS) and east-west (EW) directions] under four subduction source earthquake event scenarios acting as a seismic load on the dam structure. Due to incomplete data related to the acceleration time histories from the Java subduction source, all acceleration time histories used in this study were collected from international ground motion databases. All acceleration time histories cannot be used directly for dam stability analysis. All acceleration time histories should be matched with the seismic mechanism of the Java subduction source.

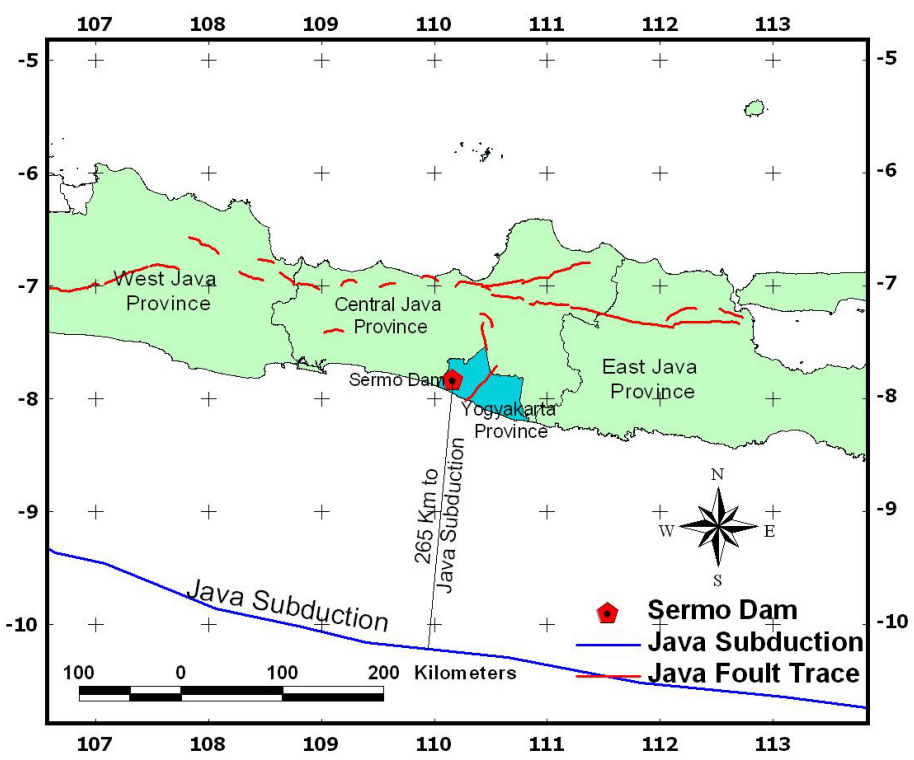

Fig. 1. Position of Sermo dam in relation to two seismic sources.

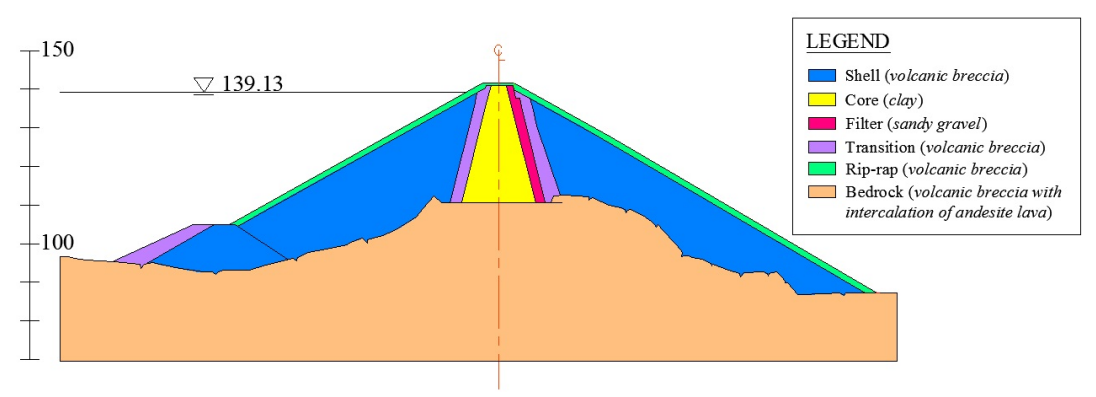

Fig. 2. Sermo dam cross section. 


\section{Geotechnical information on Sermo dam}

Sermo dam is a typical rockfill-embankment dam and was constructed on a bedrock (volcanic breccias intercalated with andesite lava formation) elevation. The main dam body can be separated into four different zones, namely the shell, filter, transition, and core zones. All information related to the soil and rock properties was collected from the Department of Public Works (1994). Table 1 describes all soil and rock properties used in the analysis. All information related to the position of each zone can be seen in Figure 2. Two parameters used for the propagation and dynamic analysis of Sermo dam are the primary wave velocity $(\mathrm{Vp})$ and the shear wave velocity $(\mathrm{Vs})$ and are developed based on [1].

Table 1 Soil and rock parameters of Sermo dam structure.

\begin{tabular}{|c|l|c|c|c|c|c|}
\hline No & Soil and Rock Parameters & Bedrock & Shell & Transition & Filter & Core \\
\hline \multirow{2}{*}{1} & $\gamma_{\text {saturated }}\left(\mathrm{kN} / \mathrm{m}^{3}\right)$ & 21.82 & 21.00 & 21.70 & 21.00 & 18.74 \\
\cline { 2 - 7 } & $\gamma_{\text {unsaturated }}\left(\mathrm{kN} / \mathrm{m}^{3}\right)$ & 20.12 & 20.00 & 21.60 & 18.50 & 15.41 \\
\hline 2 & Cohesion $(\mathrm{C})\left(\mathrm{kN} / \mathrm{m}^{2}\right)$ & 680 & 0.001 & 0.001 & 0.001 & 8.3 \\
\hline 3 & Friction Angle $(\varnothing)($ degree $)$ & 55 & 43 & 35 & 35 & 32 \\
\hline 4 & $\begin{array}{l}\text { Permeability coefficient }(k) \\
(\mathrm{m} / \text { day) }\end{array}$ & 8.53 & 12154.69 & 14.292 & 134.1 & $2.32 \times 10^{-4}$ \\
\hline 5 & Young's modulus E $\left(\mathrm{kN} / \mathrm{m}^{2}\right)$ & 320000 & 200000 & 150000 & 150000 & 100000 \\
\hline 6 & Poisson's ratio $(v)$ & 0.45 & 0.35 & 0.30 & 0.30 & 0.45 \\
\hline 7 & Vs $(\mathrm{m} / \mathrm{s})$ & 231 & 148 & 171 & 187 & 158 \\
\hline 8 & Vp $(\mathrm{m} / \mathrm{s})$ & 768 & 491 & 357 & 458 & 330 \\
\hline
\end{tabular}

\section{Modification of acceleration time histories}

New Indonesian seismic hazard maps were already developed by [2] in 2017. The most important information related to the development of all the maps is the maximum magnitude of all seismic sources within the whole area of Indonesia, which can be used for building and infrastructure design and evaluations. Based on the information developed by [2], the maximum magnitude that can be used for engineering design and evaluation related to Java subduction earthquake scenarios is $8.5 \mathrm{Mw}$. All acceleration time histories used in this study for stability analysis of Sermo dam were collected for a subduction megathrust earthquake mechanism with a magnitude of 7.9 to $8.4 \mathrm{Mw}$ and epicentre distance of 167.7 to $394 \mathrm{Km}$.

Due to incomplete data related to the magnitude and distance of every earthquake event, all acceleration time histories used in this study were collected with magnitude and distance close to the engineering requirements for Java subduction sources. Table 2 shows all of the information related to the seismic magnitude and epicentre distance of all seismic events used in this study. All subduction acceleration time history data were collected from the Center for Engineering Strong Motion Data (CESMD). Figure 3(a) shows the original twocomponent acceleration time histories for the NS and EW directions of South Sumatera earthquake. Figure 3(b) shows the original two-component acceleration time histories for the NS and EW directions of Mentawai earthquake.

All acceleration time histories collected from external earthquake events for dam analysis should be modified to obtain matched acceleration time histories under the 
earthquake scenarios caused by the Java subduction megathrust. To perform the matching analysis, a set of spectral acceleration targets was developed using deterministic hazard analysis and conducting three ground motion prediction equations (GMPE). Three equations proposed by [3-5] were conducted in this study for the Java subduction earthquake scenarios. Response spectral matching analysis was performed to obtain modified (matched) acceleration time histories. The spectral matching analysis was implemented following the same methods as conducted by [6]. Figures 4(a) and 4(b) show two examples of spectral acceleration targets for the South Sumatera and Mentawai earthquakes respectively. Figures 5(a) and 5(b) are two examples of matched acceleration time histories for South Sumatera and Mentawai earthquakes developed from the response spectral matching analysis.

Table 2. Acceleration time histories for subduction megathrust used in this study.

\begin{tabular}{|c|c|c|}
\hline Seismic Sources & $\begin{array}{c}\text { Epicentre Distance } \\
(\mathbf{K m})\end{array}$ & $\begin{array}{c}\text { Magnitude } \\
(\mathbf{M w})\end{array}$ \\
\hline Illapel, Chille (2015) & $235 \mathrm{Km}$ & 8.3 \\
\hline Kodiak, Alaska (2018) & $281.4 \mathrm{Km}$ & 7.9 \\
\hline South Sumatera, Indonesia (2007) & $394 \mathrm{Km}$ & 8.4 \\
\hline Mentawai, Indonesia (2007) & $167.7 \mathrm{Km}$ & 7.9 \\
\hline
\end{tabular}
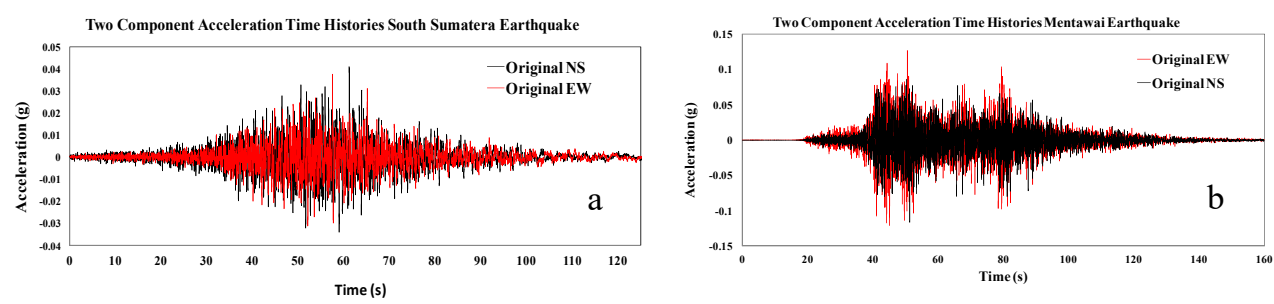

Fig. 3. Two-component original time histories of South Sumatera (a) and Mentawai (b) earthquakes.
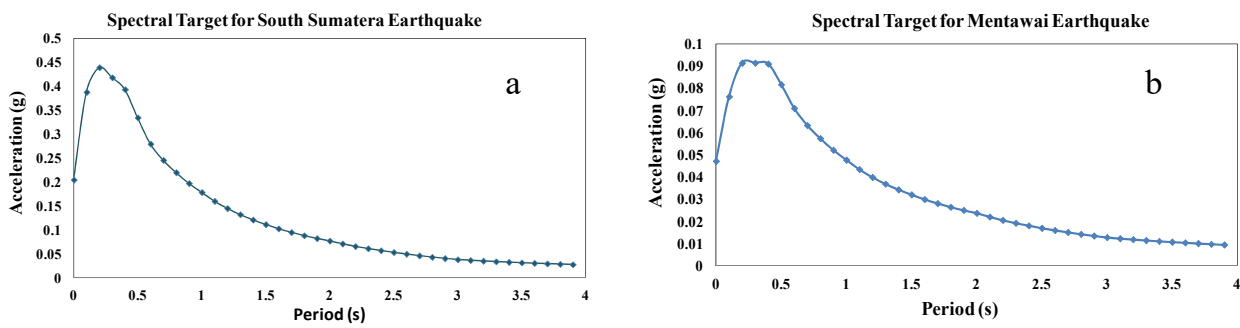

Fig. 4. Spectral target for South Sumatera (a) and Mentawai (b) earthquakes.
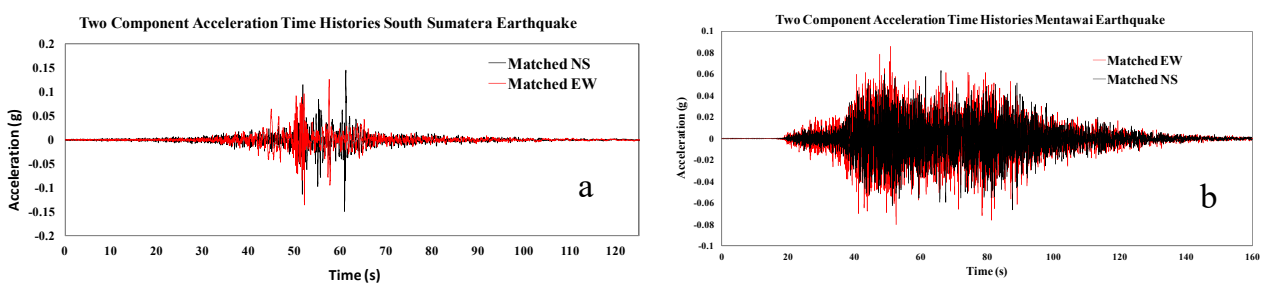

Fig. 5. Two-component matched time histories of South Sumatera (a) and Mentawai (b) earthquakes. 


\section{Stability analysis of Sermo dam}

The stability analysis of Sermo dam was conducted using a 2D model to find the maximum displacement and PGA of the dam embankment due to a combination of dead, hydrostatic, and earthquake loads. The earthquake loading was performed by conducting acceleration time histories for different earthquake events. Total displacement was calculated based on two direction displacements, vertical and horizontal. PGA values developed from propagation analysis were also investigated at the core zone to find the information on the PGA profile from the bedrock elevation to the top dam elevation. The displacement and PGA values were investigated at six positions of the core zone. Figure 6 shows the positions of six points (A, B, C, D, E, and F) for measuring the displacement and PGA outputs. Figure 7(a) shows the total displacement of the dam under the South Sumatera earthquake scenario. Figure 7(b) shows the PGA profile of Sermo dam under the South Sumatera earthquake scenario.

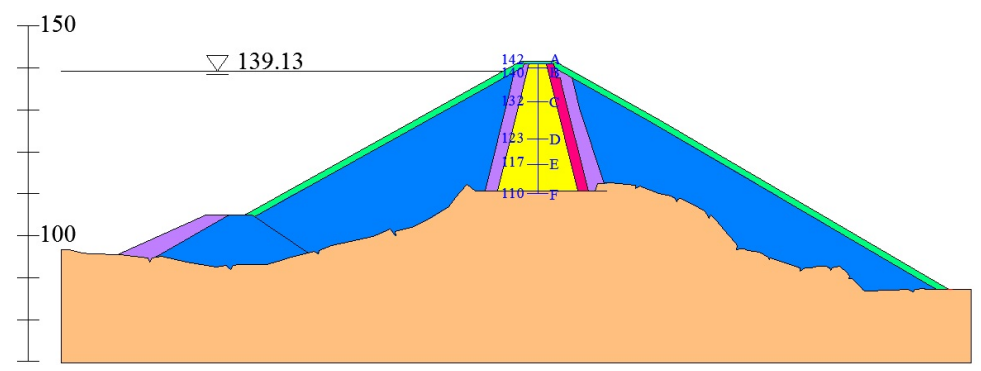

Fig. 6. Position of displacement and PGA data collection.
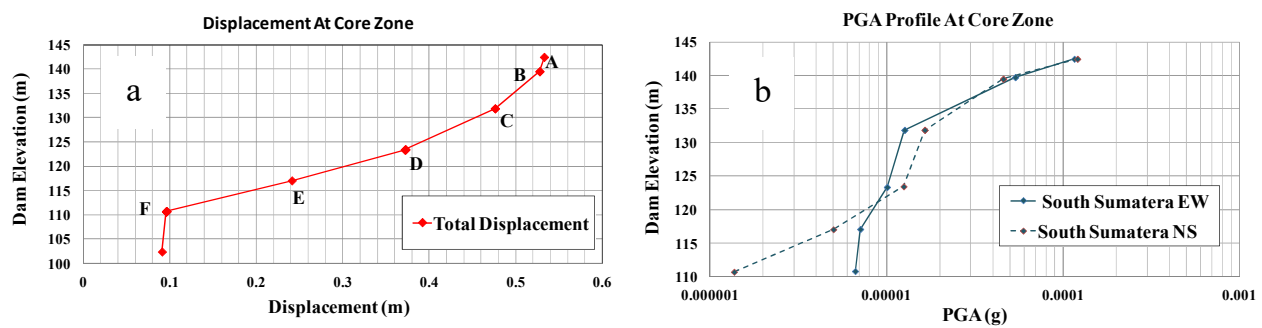

Fig. 7. Displacement (a) and PGA profile (b) under South Sumatera earthquake.

\section{Results and discussion}

Stability analysis of Sermo dam was conducted in two steps. The first evaluation was conducted without seismic load and the next evaluation was performed by applying four different seismic scenarios. The purpose of this two-step evaluation was to obtain the sensitivity results of seismic loads compared with the real condition of Sermo dam without any seismic loads. The investigation was performed at six positions of the core zone. The average displacements under all five scenario loads at points $\mathrm{A}, \mathrm{B}, \mathrm{C}, \mathrm{D}, \mathrm{E}$, and $\mathrm{F}$ are $0.5324 \mathrm{~m}, 0.5274 \mathrm{~m}, 0.4756 \mathrm{~m}, 0.3742 \mathrm{~m}, 0.2416 \mathrm{~m}$, and $0.097 \mathrm{~m}$ respectively. The average safety factor calculated using all seismic loads is 1.4508 ; however, the safety factor for the non-seismic load condition is 1.51 .

Based on the results of the stability analysis calculated with and without seismic loads, it can be seen that the total displacements of Sermo dam are almost equal. Figure 8(a) shows the average total displacement results of the dam due to all loads. Figure 8(b) shows the PGA profile calculated using four seismic scenarios. The maximum PGA value is less than $0.0001 \mathrm{~g}$ (gravitational acceleration $\left.=9.81 \mathrm{~m} / \mathrm{s}^{2}\right)$. Based on the average displacement 
and PGA values it can be predicted that Sermo dam is strong enough to resist an earthquake with a maximum magnitude of $8.4 \mathrm{Mw}$ and minimum epicentre distance of $167.7 \mathrm{Km}$ caused by the Java subduction.
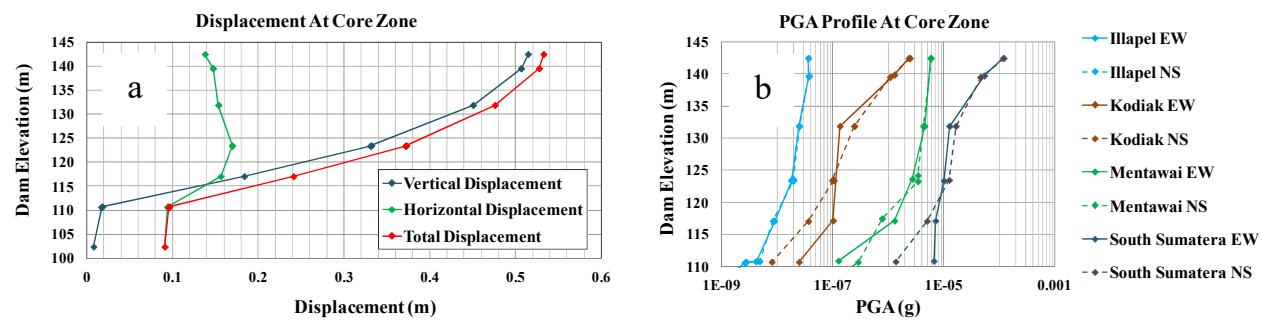

Fig. 8. Horizontal, vertical, and total displacements in the core zone based on five scenario loads (a), PGA profile in the core zone based on four earthquake scenarios (b).

\section{Conclusions}

A stability evaluation of Sermo dam, Yogyakarta, was performed in this study. The purpose of this evaluation was to determine the stability performance and PGA values of this structure against seismic load scenarios. The evaluation was performed by considering four different earthquake scenarios caused by the Java subduction megathrust source with magnitudes of 7.9 to $8.4 \mathrm{Mw}$ and epicentre distances of 167.7 to $394 \mathrm{Km}$.

Based on the total displacement results calculated using four earthquake scenarios and the results calculated for the original dam condition without earthquake loads, it seems that all of the results of the displacement analysis are almost equal. The maximum PGA value investigated in the core zone of the dam is $0.0001 \mathrm{~g}$. Based on these two pieces of information, Sermo dam is predicted to be strong enough to resist an earthquake caused by Java subduction megathrust earthquake with a maximum magnitude of $8.4 \mathrm{Mw}$ and minimum epicentre distance of approximately $160 \mathrm{Km}$.

\section{References}

1. S.L. Kramer, Geotechnical earthquake engineering, Prentice Hall Int. (1996)

2. Pusat Studi Gempa Nasional, Peta Sumber dan Bahaya Gempa Indonesia Tahun 2017, Pusat Penelitian Perumahan dan Pemukiman, Kementerian Pekerjaan Umum dan Perumahan Rakyat (National Center for Earthquake Studies, Indonesian Seismic Sources and Seismic Hazard Maps 2017, Center for Research and Development of Housing and Resettlement, Ministry of Public Works and Human Resettlements), ISBN 978-602-5489-01-3 (2017)

3. R.R. Youngs, S.J. Chiou, W.J. Silva, J.R. Humprey, Seismol, Res. Lett. 68, 58-73 (1997)

4. G.M. Atkinson, D. M. Boore, Bull. Seis.Soc. of Am., 93, 4, 1703-1729 (2003)

5. J.X. Zhao, J. Zhang, A. Asano, Y. Ohno, T. Oouchi, T. Takahashi, H. Ogawa, K. Irikura, H. Thio, P. Somerville, Bull. Seismol. Soc. Am., 96, 898 (2006)

6. N.A. Abrahamson, Non Stationary Spectral Matching Program RSPMATCH>PG\&E, Internal Report (1998) 